\section{Nickel accelerates pyrite nucleation at ambient temperature}

\author{
G. Morin ${ }^{1 *}$, V. Noëll,2,3,4, N. Menguy ${ }^{1}$, J. Brest ${ }^{1}$, B. Baptiste ${ }^{1}$, \\ M. Tharaud ${ }^{4}$, G. Ona-Nguema', M. Ikogou' ${ }^{1}$, E. Viollier ${ }^{4}$, F. Juillot ${ }^{1,5}$
}

Abstract

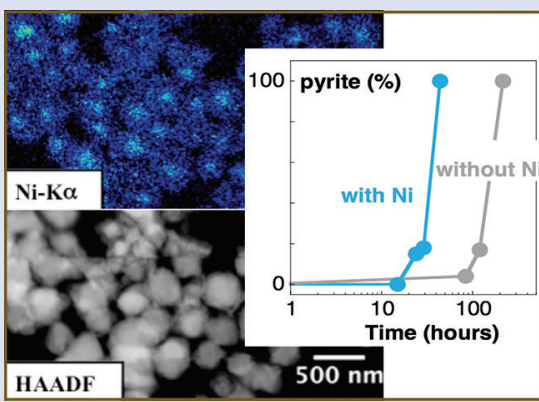

Chemical and isotopic compositions of pyrites are used as biogeochemical tracers in Archean to modern sediments. Moreover, pyrite formation from monosulphide precursors has been proposed to be involved in prebiotic chemistry. However, the factors controlling pyrite formation and distribution in the sedimentary record are incompletely understood. Here, we show that $\mathrm{Ni}^{2+}$ ions accelerate $\sim 5$ times the nucleation of pyrite at ambient temperature. Using Fe and Ni K-edge EXAFS and TEM-EDXS we demonstrate that $\mathrm{Ni}$ (II) is directly involved in the nucleation of pyrite synthesised by reacting $\mathrm{Fe}(\mathrm{III})$ with $\mathrm{Na}_{2} \mathrm{~S}$ in the presence of aqueous $\mathrm{Ni}(\mathrm{II})$ impurity. Initial formation of a Ni-enriched pyrite core is followed by overgrowth of a Ni-depleted pyrite shell, leading to compositional zoning of the $\mathrm{Fe}_{1-x} \mathrm{Ni}_{x} \mathrm{~S}_{2}$ nanocrystals ( $x=0.05$ to 0.0004 ). The molar $\mathrm{Ni} / \mathrm{Fe}$ ratio in the final aqueous solution was then 2000 times lower than the starting ratio of 0.01 . This enhanced and accelerated trapping of $\mathrm{Ni}$ by pyrite could be of prime importance in controlling Ni concentration in the ocean during early diagenesis of marine sediments, and could thus have important implications for interpreting abundances of $\mathrm{Ni}$ and pyrite in the sedimentary record. In addition, acceleration of pyrite nucleation in the presence of nickel could help understanding the role of $\mathrm{Fe}-\mathrm{Ni}$ sulphides in catalysing potential prebiotic reactions.

Received 10 May 2017 | Accepted 8 September 2017 | Published 18 October 2017

\section{Introduction}

Pyrite is widely used as a geochemical marker in sediments from the Archean to modern eras. Isotopic compositions of iron and sulphur in pyrites from sedimentary rocks have been proposed as potential proxies to assess the redox state of ancient oceans (Rouxel et al., 2005; Reinhard et al., 2009; Marin-Carbonne et al., 2014), the oxygen outgrowth in the atmosphere (Catling and Claire, 2005; Ohmoto et al., 2006) and early microbial metabolisms (Johnson et al., 2008). Moreover, trace metals incorporated in pyrite have been recognised as proxies for ancient ocean chemistry (Large et al., 2017). Besides, the formation of pyrite from a $(\mathrm{Fe}, \mathrm{Ni}) \mathrm{S}$ precursor has been proposed to be involved in the 'Fe-S World' theory of the origin of life (Huber and Wächtershäuser, 1997, 1998). In parallel, nickel has been recognised as an essential biocatalytic metal agent in iron-sulphur enzymes, especially acetyl-CoA synthase, which is a major enzyme of acetogenic bacteria and methanogens for fixing $\mathrm{CO} / \mathrm{CO}_{2}$ (Darnaud et al., 2003). Lastly, nickel has a particular ability to be incorporated in pyrite during early diagenesis of marine and coastal sediments
(Huerta-Diaz and Morse, 1992; Morse and Luther, 1999; Large et al., 2017), which largely contributes to $\mathrm{Ni}$ immobilisation in mangroves (Noël et al., 2014, 2015). The image that arises is one in which pyrite is a regulator of iron and trace metal distribution in modern and ancient environments. Conversely, the possible effects of metal impurities such as nickel on the formation of pyrite have not been investigated yet, especially at low-temperature (Morse and Luther, 1999; Rickard and Luther, 2007). Here we show that $\mathrm{Ni}^{2+}$ as impurity drastically accelerates pyrite formation at ambient temperature under early diagenesis-like conditions, thus suggesting that Ni impurities might have influenced the distribution and abundance of pyrite and nickel in the present and ancient sedimentary record.

\section{Materials and Methods}

Pyrite $\left(\mathrm{FeS}_{2}\right)$ was synthesised by reacting ferric chloride with sodium sulphide in aqueous solution for two weeks at room temperature under strict anoxic conditions (Noël et al., 2014,

\footnotetext{
1. Institut de Minéralogie, de Physique des Matériaux et de Cosmochimie (IMPMC), UMR 7590, CNRS, UPMC-Sorbonne Universités, MNHN, IRD, 4 place Jussieu, 75005 Paris, France

Corresponding author: (e-mail: guillaume.morin@upmc.fr)

2. Koniambo Nickel SAS (KNS), B.P.679, 98860 Koné, New Caledonia

Stanford Synchrotron Radiation Lightsource, SLAC National Accelerator Laboratory, Menlo Park, California 94025, USA

Equipe de Géochimie des Eaux de l’Institut de Physique du Globe (IPGP), UMR 7154, 1 rue Jussieu, 75005 Paris, France

Institut de Recherche pour le développement (IRD), UR 206/UMR 7590 IMPMC, 98848 Nouméa, New Caledonia
} 


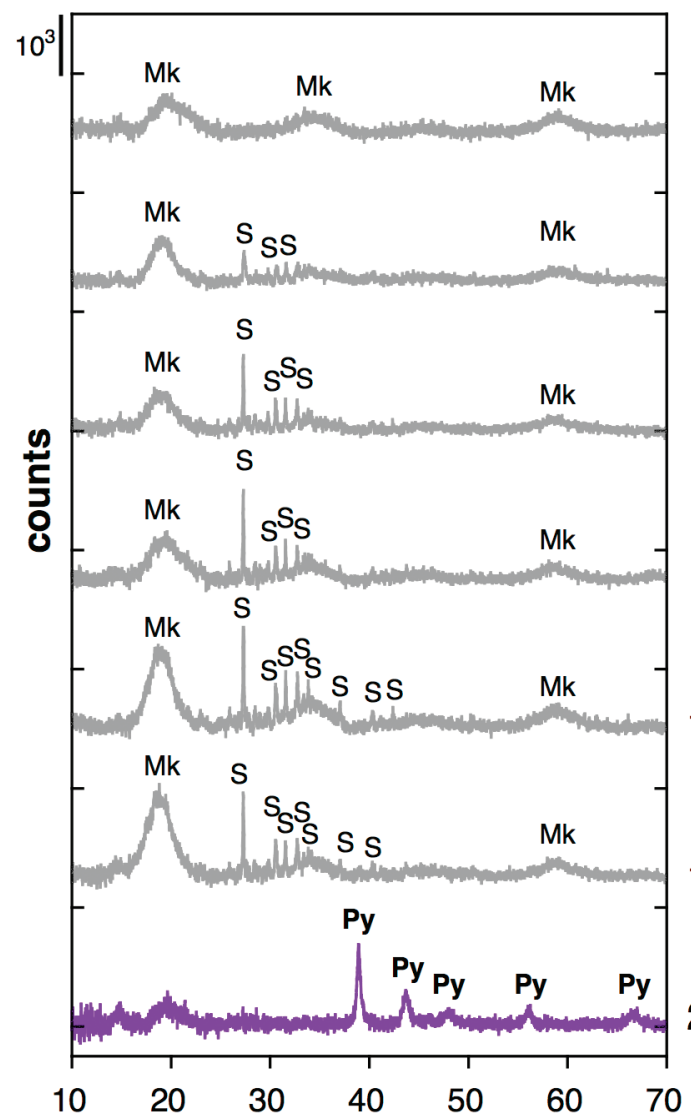

$2 \theta\left({ }^{\circ}\right)$ Co K $\alpha$
$0.5 \mathrm{hr}$

$24 \mathrm{hr}$

$48 \mathrm{hr}$

$84 \mathrm{hr}$

$120 \mathrm{hr}$

$180 \mathrm{hr}$

$216 \mathrm{hr}$

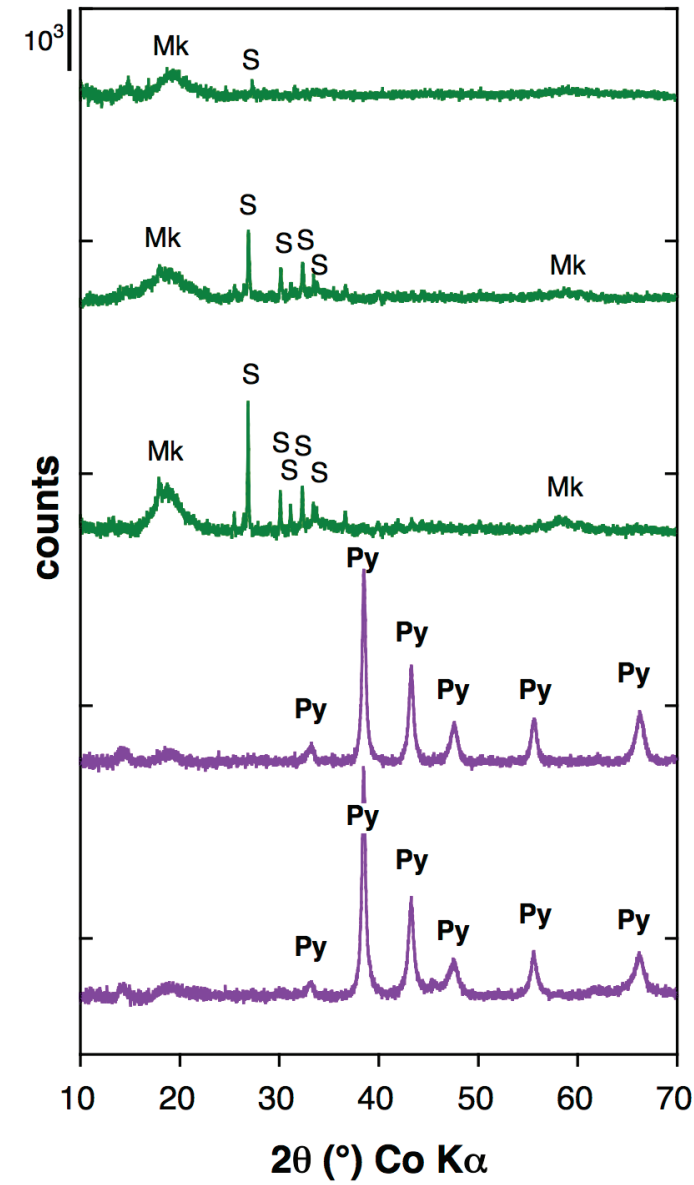

$0.5 \mathrm{hr}$

$4 \mathrm{hr}$

$29 \mathrm{hr}$

$48 \mathrm{hr}$

$216 \mathrm{hr}$

Figure 1 Aqueous nickel impurity accelerates the formation of pyrite from a $\mathrm{FeS}_{(\mathrm{m})}$ precursor. Powder XRD patterns of the solids collected over the course of the pyrite synthesis experiments conducted at room temperature in the absence (left) or presence (right) of aqueous $\mathrm{Ni}$ in the starting solution. Mk: nano-mackinawite; S: a-sulphur; Py: pyrite.

2015), with or without nickel chloride as impurity $(\mathrm{Ni} / \mathrm{Fe}=0.01$ $\mathrm{mol} / \mathrm{mol})$ in the starting solution $\left(\sum \mathrm{Fe}(\mathrm{III})+\mathrm{Ni}(\mathrm{II})=\sum \mathrm{S}(-\mathrm{II})=\right.$ $50 \mathrm{mM}$ at $\mathrm{pH}$ 5.5; Table S-1). Over the course of pyrite formation, the solid and aqueous phases were sampled by centrifugation and $0.2 \mu \mathrm{m}$ filtration. Aqueous Fe and Ni concentrations were measured by ICP-AES and HR-ICP-MS, respectively. The mineralogy of the solid samples was determined by powder $X$-ray diffraction (XRD) and wide-angle $X$-ray scattering (WAXS) - pair distribution function (PDF) under anoxic conditions. The nano-scale distribution of Fe and Ni was mapped by scanning transmission electron microscopy (STEM) in high angle annular dark field (HAADF) coupled with energy dispersive X-ray analysis (EDXS). The molecular environment of $\mathrm{Ni}$ and Fe was probed by using extended X-ray absorption fine structure (EXAFS) spectroscopy. EXAFS spectra of the pyrite end products were least squares fitted to theoretical $a b$ initio spectra calculated with the Feff8.1 code. EXAFS spectra of the solids collected over the course of the experiments were analysed by linear combination least squares (LC-LS) fitting using a large model compounds spectra database (Noël et al., 2014, 2015). Detailed procedures are reported in Supplementary Information.

\section{Results and Discussion}

Mineralogical sequence leading to pyrite formation. The first solid phase that formed in our pyrite synthesis experiments was nanocrystalline mackinawite, $\mathrm{FeS}_{(\mathrm{m})}$ (Lennie et al., 1995; Rickard and Luther, 2007), rapidly followed by the crystallisation of minor amounts of $\mathrm{S}(0)_{(\text {alpha) }}$ (Fig. 1). After an extended lag phase, pyrite rapidly formed at the expense

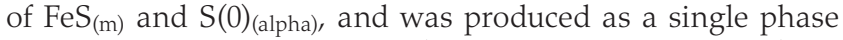
at the end of all experiments (Figs. 1, S-1 and Table S-2). Fe K-edge EXAFS spectra of the Ni-free (Fig. S-2 and Table S-3) and of the Ni-doped end products (Fig. $2 \mathrm{~b}$ and Table S-3) well matched pyrite crystallographic data (Wyckoff, 1963).

This mineralogical sequence is consistent with pyrite formation pathways at low temperature via a $\mathrm{FeS}_{(\mathrm{m})}$ precursor (Berner, 1970; Rickard, 1975; Schoonen and Barnes, 1991). Accordingly, in our experiments, Fe(III) species rapidly reacted with aqueous $\mathrm{H}_{2} \mathrm{~S}$ to form iron monosulphide $\mathrm{FeS}_{(\mathrm{m})}$ and $\mathrm{S}(0)_{(\text {alpha) }}$ :

$$
\begin{gathered}
\mathrm{Fe}(\mathrm{OH})_{2}{ }_{(\mathrm{aq})}+\mathrm{H}_{2} \mathrm{~S}_{(\mathrm{aq})} \stackrel{1}{\rightarrow} / 2 \mathrm{FeS}_{(\mathrm{m})} \\
+1 / 2 \mathrm{~S}(0)_{(\mathrm{alpha})}+1 / 2 \mathrm{Fe}^{2+}{ }_{(\mathrm{aq})}+2 \mathrm{H}_{2} \mathrm{O}_{(\mathrm{l})}
\end{gathered}
$$

After the lag phase, $\mathrm{FeS}_{(\mathrm{m})}$ then fully converted to $\mathrm{FeS}_{2 \text { (pyrite) }}$ as summarised by:

$$
1 / 2 \mathrm{FeS}_{(\mathrm{m})}+1 / 2 \mathrm{~S}(0)_{(\text {alpha) }} \leftrightarrows 1 / 2 \mathrm{FeS}_{2 \text { (pyrite) }}
$$

According to Rickard (1975), this conversion actually proceeds via the reaction between aqueous polysulphide ions $\mathrm{S}_{\mathrm{n}}{ }^{2-}$ (aq) in equilibrium with $\mathrm{S}(0)$, and aqueous $[\mathrm{FeS}]_{p(\text { aq })}$ oligomers in equilibrium with $\mathrm{FeS}_{(\mathrm{m})}$ (Rickard, 1975; Luther, 1991; Theberge and Luther, 1997; Rickard and Morse 2005; Rickard and Luther 2007), e.g., for $p=1$ :

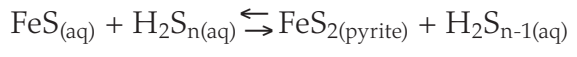

Eq. 3 
(a)

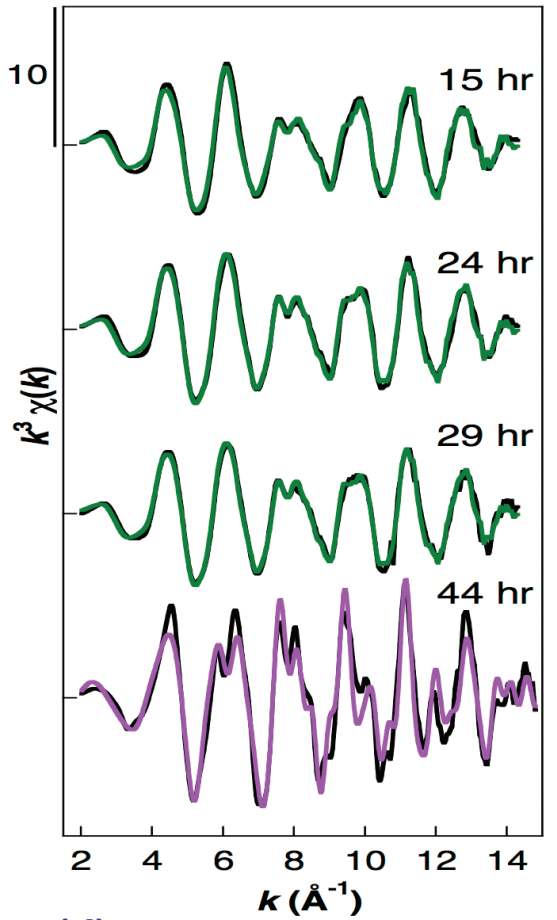

(d)

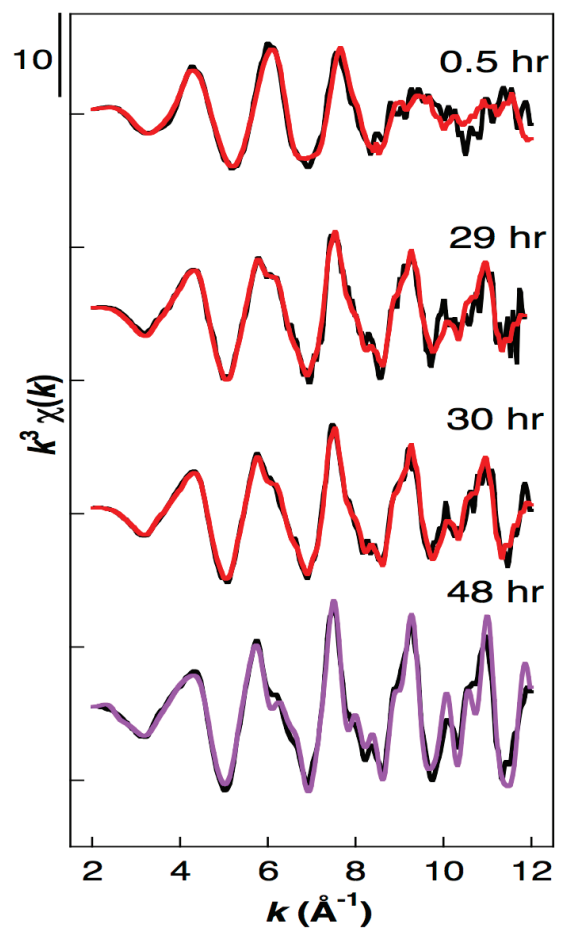

(b)

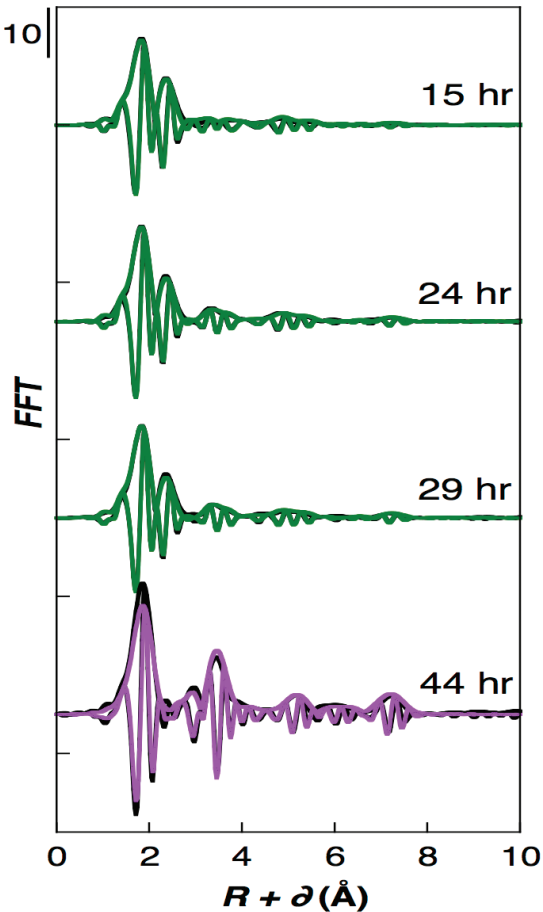

(e)

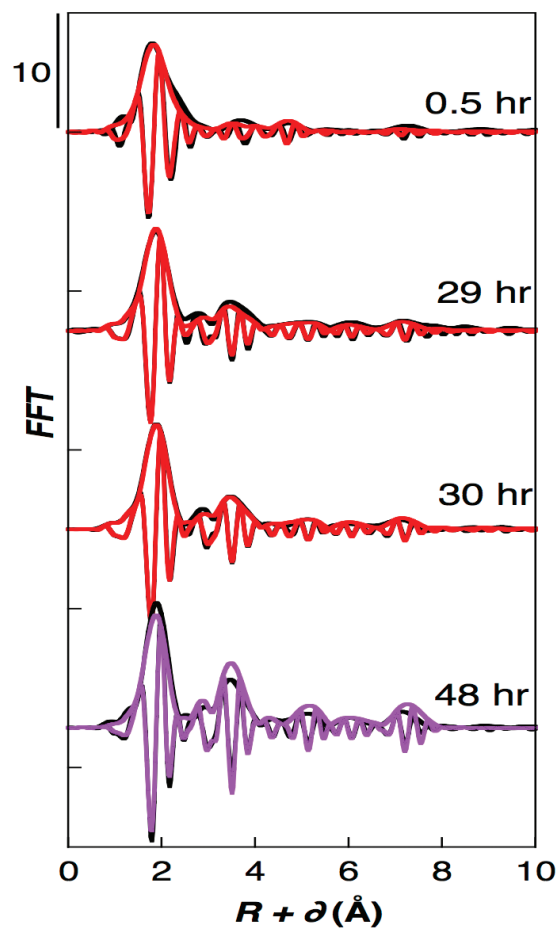

(c)

Time (hr)

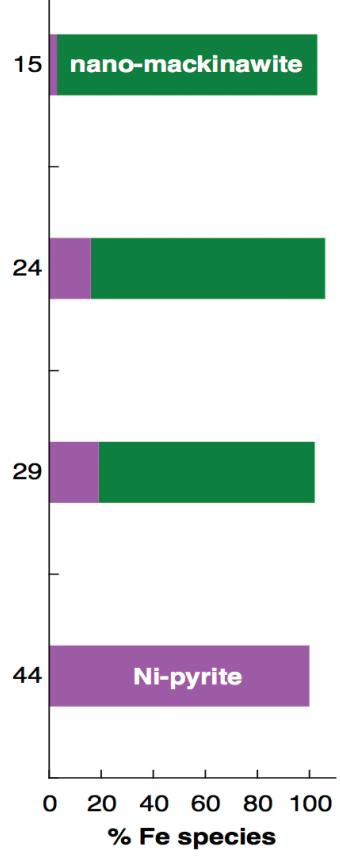

(f)

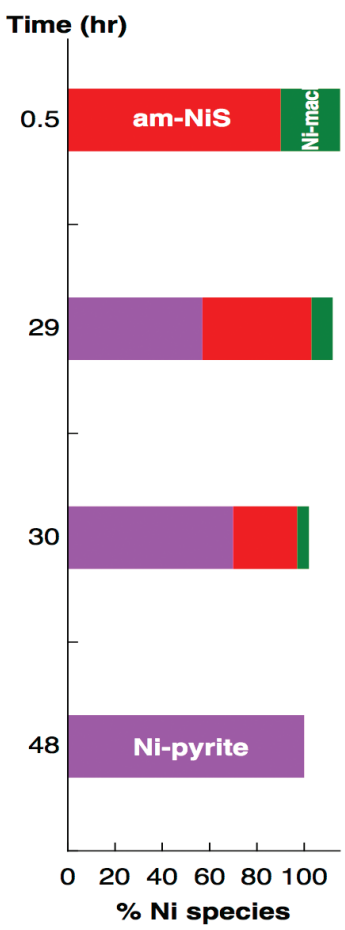

Figure 2 Fe and Ni speciation in the solids formed during the synthesis of Ni-doped pyrite. Fe (a,b) and Ni (d,e) K-edge $k^{3}$-weighted EXAFS spectra and corresponding Fast Fourier transforms. Experimental (black). Ab initio Feff8.1 calculation (purple) (Table S-3). LC-LS fits (green: Fe; red: Ni) (Table S-4). LC-LS fit components probing the local structure around Fe (c) and Ni (f) atoms include: Ni-pyrite $\left(\mathrm{Fe}_{1-x} \mathrm{Ni}_{x} \mathrm{~S}_{2}\right)$, am-NiS (amorphous NiS) and Ni-mack $\left(\mathrm{Fe}_{1-x} \mathrm{Ni}_{x} \mathrm{~S}\right)$ (Table S-4).

Effect of $\mathrm{Ni}^{2+}$ on pyrite nucleation. The mineralogical sequence was similar with or without the addition of $\mathrm{Ni}^{2+}$ in the starting solution, but with major changes in the kinetics of pyrite nucleation. XRD showed that Ni dramatically shortened the lag phase before pyrite formation (Fig. 1). Moreover, Fe and $\mathrm{Ni}$ K-edge EXAFS that probed the local environment of Fe and $\mathrm{Ni}$ atoms at a 3-8 $\AA$ scale enabled us to catch the nucleation of pyrite before it was detected by XRD. Indeed, Fe EXAFS showed that $20 \%$ of iron was present in pyrite clusters after
24 hours (Fig. 2a,b,c and Table S-4) for the synthesis with Ni but only after 120 hours without Ni (Fig. S-2), while pyrite was not detected by XRD at these respective reaction times (Fig. 1). Pyrite nucleation thus started $\sim 5$ times earlier with Ni than without Ni. Furthermore, Ni EXAFS showed that more than $50 \%$ of nickel was incorporated in pyrite nuclei within the first 29 hours of the synthesis with Ni (Fig. 2d,e,f and Table S-4), before pyrite could be detected by XRD (Fig. 1). In addition, at the earliest stage of the synthesis with $\mathrm{Ni}(0.5 \mathrm{hr}) \mathrm{Ni}$ was 
mainly present as amorphous NiS ( 80\%) with a minor fraction of $\mathrm{Ni}$ incorporated in nano-mackinawite ( $20 \%$; Fig. 2 and Table S-4). At the end of the synthesis (48 hr), Ni was fully incorporated in pyrite, as indicated by the good match between experimental and $a b$ initio calculated EXAFS spectra (Fig. 2d,e and Table S-4). Altogether, XRD and EXAFS results thus demonstrated that $\mathrm{Ni}^{2+}$ accelerated pyrite formation through the early nucleation of $\mathrm{Ni}$-enriched pyrite.

Compositional zoning of the pyrite crystals at the nanoscale. STEM-EDXS mapping of the Ni-doped pyrite end product showed that $\mathrm{Ni}$ was preferentially located in the inner core of the pyrite crystals (Fig. 3). This was in agreement with the preferential uptake of $\mathrm{Ni}$ during pyrite nucleation shown by EXAFS analysis (Fig. 4a). Assuming saturation equilibrium, the composition of an ideal solid solution $\mathrm{Fe}_{1-x} \mathrm{Ni}_{x} \mathrm{~S}_{2}$ can be predicted from the solution composition using a theoretical partition coefficient (Bruno et al., 2007): $\mathrm{D}=K s_{\mathrm{Py}} / \mathrm{K}_{s_{\mathrm{Va}}}=\left[\mathrm{Fe}_{\mathrm{aq}}\right] /$ $\left[\mathrm{Ni}_{\mathrm{aq}}\right] \cdot x /(1-x)$ (Tables S-5 and S-6). According to this model, the first pyrite nuclei should have been significantly enriched in Ni ( $x=4.9$ mol. \% Ni ideal; Fig. 4b and Table S-6) with respect to the aqueous $\mathrm{Ni} / \mathrm{Fe}$ ratio $(0.013 \mathrm{~mol}$. \%) measured by ICP at the end of the lag phase. This enrichment that agrees with so-called "common salt effect" is consistent with the $x$ value of 5.4 mol. \% Ni observed for the first pyrite nuclei that formed after 24-29 hours, as calculated by combining EXAFS (Fig. 2 and Table S-3) and aqueous chemistry data (Table S-6). The $x$ value of the pyrite overgrowth is then expected to have rapidly decreased after 48 hours, as confirmed by EXAFS (Fig. $4 \mathrm{~b}$ and Table S-6), and to have almost vanished after 100 hours of synthesis (Fig. 4b and Table S-6). The compositional zoning of our synthetic Ni-doped pyrite nanocrystals (Fig. 3) can hence be interpreted as successive overgrowth of ideal solid solutions with decreasing Ni substitution rate.
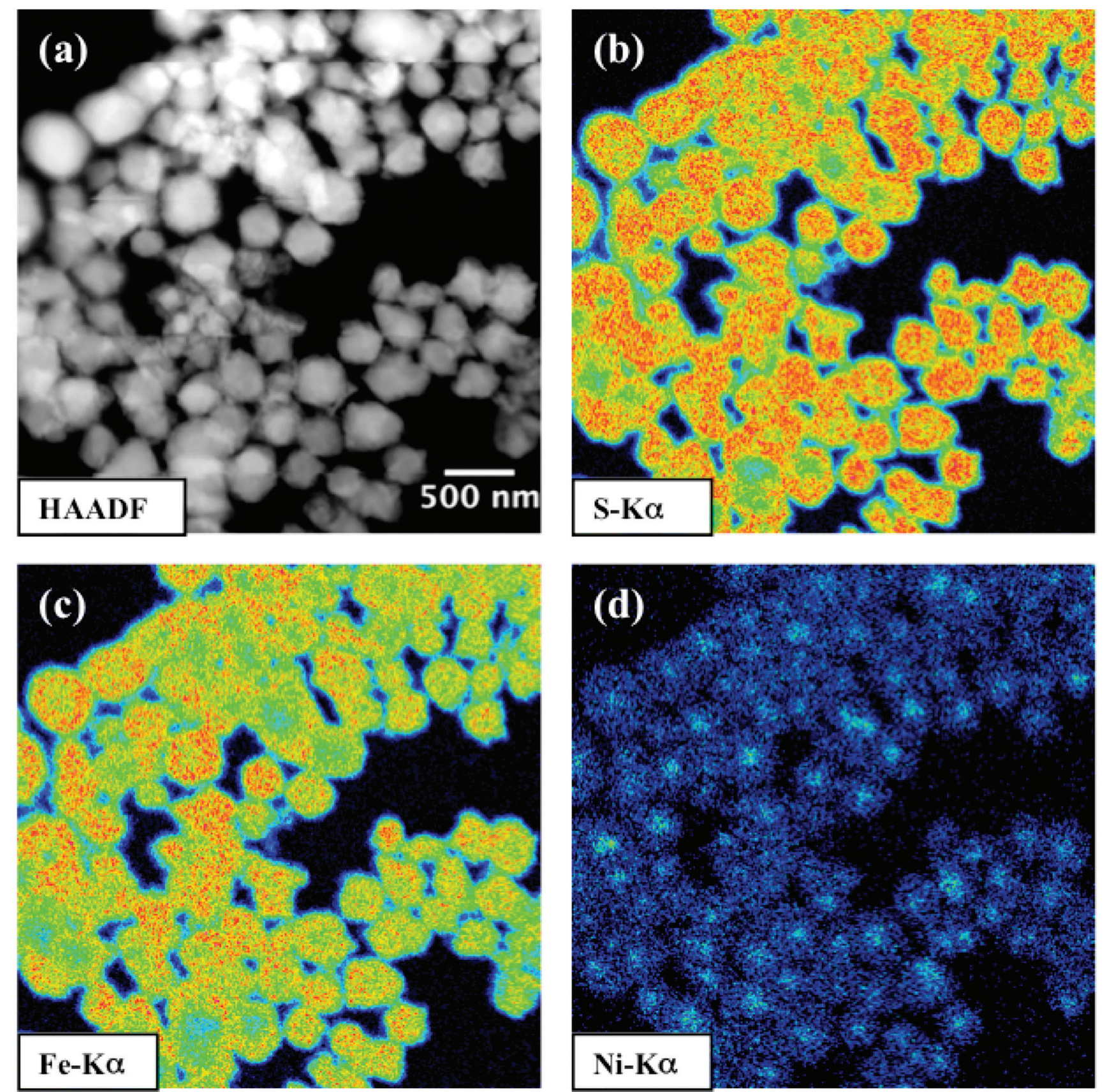

Figure 3 Compositional zoning of the pyrite nanocrystals. STEM-HAADF images and TEM-EDXS mapping of the pyrite particles collected at $48 \mathrm{hr}$, from the experiment performed with aqueous Ni. Elemental maps show that $\mathrm{Ni}$ is preferentially located into the core of the pyrite crystals. Elemental abundances increase from blue to green and to red colours. 
(a)

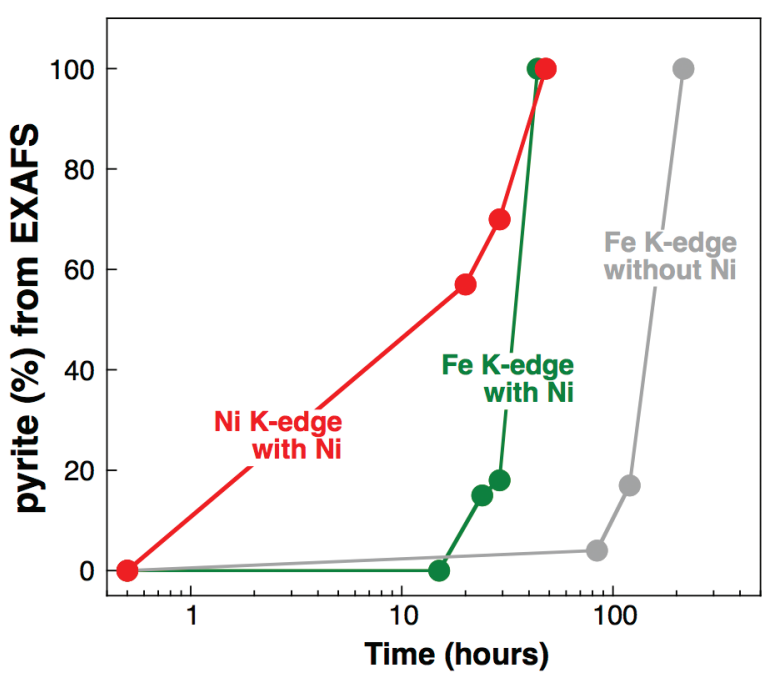

(b)

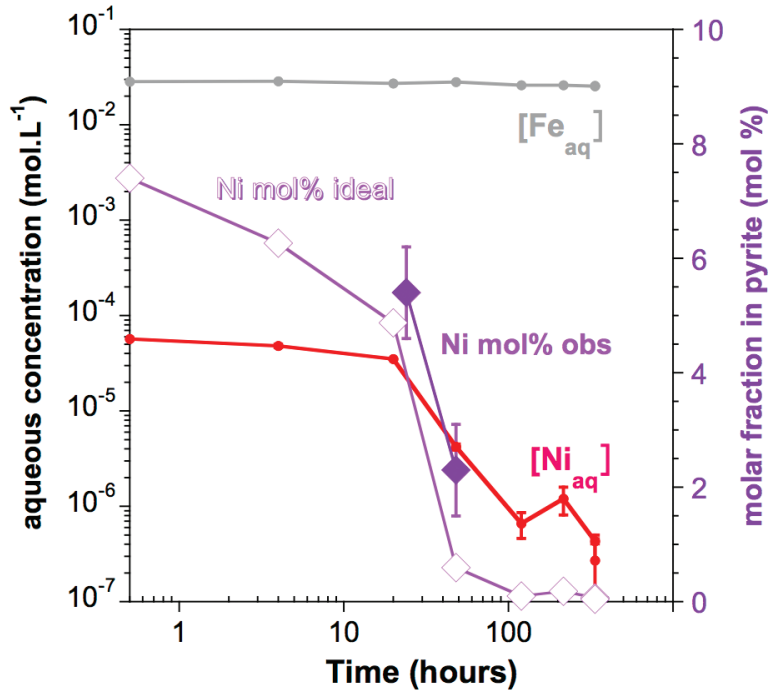

Figure 4 Distribution of $\mathrm{Ni}$ and $\mathrm{Fe}$ in the solid and dissolved phases during the pyrite synthesis. (a) Proportion of initial Ni (red) and Fe (green and gray) incorporated in pyrite in the synthesis conducted with and without Ni impurity, as determined by LC-LS fits of EXAFS data (Figs. 2 and S-2). (b) Concentrations of aqueous $\mathrm{Fe}\left(\left[\mathrm{Fe}_{\mathrm{aq}}\right]\right.$ ) and $\mathrm{Ni}\left(\left[\mathrm{Ni}_{\mathrm{aq}}\right]\right.$ ) in the presence (with $\mathrm{Ni}$ ) and absence (without $\mathrm{Ni}$ ) of aqueous $\mathrm{Ni}$ impurity. The molar fraction of $\mathrm{Ni}$ in pyrite estimated by combining chemical composition of the solution and EXAFS analysis of the solids ( $\mathrm{Ni} \mathrm{mol.} \mathrm{\%} \mathrm{obs;} \mathrm{purple} \mathrm{diamonds)} \mathrm{is} \mathrm{compared} \mathrm{to} \mathrm{the} \mathrm{molar} \mathrm{fraction} \mathrm{of} \mathrm{Ni} \mathrm{in} \mathrm{pyrite} \mathrm{predicted} \mathrm{by} \mathrm{assuming}$ saturation equilibrium with an ideal pyrite-vaesite solid solution (Ni mol. \% ideal; white diamonds) (see text and Table S-5).

Unravelling the role of nickel in the kinetics of pyrite formation. Spontaneous pyrite nucleation is generally thought to require a saturation index as large as $\log \Omega_{\mathrm{Py}}{ }^{*}=14$ and/or catalytic effects (Harmandas et al., 1998; Rickard and Luther, 2007). Within the first 30 minutes of our synthesis with $\mathrm{Ni}$ as impurity, amorphous NiS precipitated and a minor fraction of nickel coprecipitated with $\mathrm{FeS}_{(\mathrm{m})}$ (Fig. 2 and Table S-4) resulting in a decrease of measured aqueous $\mathrm{Ni}$ and Fe concentration down to $57 \mu \mathrm{M}$ and $28 \mathrm{mM}$, respectively (Table S-6). Based on these values that remained almost constant during the 24-29 hours lag phase (Fig. 4b), with a slight decrease for Ni (Table S-6), Chess 3.0 (van der Lee and De Windt, 2002) calculations show that the saturation index of any ideal pyritevaesite solid solutions was in between the saturation indexes of the $\mathrm{FeS}_{2 \text { (pyrite) }}$ and $\mathrm{NiS}_{2 \text { (vaesite) }}$ end members (i.e. $\log \Omega_{\mathrm{Py}}=12.3$ and $\log \Omega_{\mathrm{Va}}=9.9$, respectively). This is because the solubility products of pyrite $\left(K_{s_{\mathrm{Py}}}=10^{-14.2}\right.$; Rickard and Luther, 2007) and vaesite $\left(K s_{\mathrm{Va}}=10^{-15.8}\right.$; Gamsjäger et al., 2005) differ by less than two orders of magnitude (Table S-5). Consequently, the acceleration of pyrite nucleation in our synthesis experiment with $\mathrm{Ni}$ cannot be explained by supersaturation with respect to the solid solution, since $\log \Omega_{\mathrm{Va}}<\log \Omega_{\mathrm{Fe} 1-x \mathrm{NixS} 2}<\log \Omega_{\mathrm{Py}}<\log \Omega^{*}$.

Interfacial energy $\gamma$ is known to influence the rate of nucleation from solution (Stumm, 1992). Slightly lower $\gamma$ values for pyrite (Kitchaev and Ceder, 2016) than for vaesite (Zheng et al., 2015) would however imply a lower activation energy for the nucleation of pyrite than for vaesite and can thus not be invoked to explain the faster nucleation of $\mathrm{Ni}$-doped pyrite compared to Ni-free pyrite.

Finally, ligand exchange rates of cations correlate well with the reactivity of both divalent metal oxides (Casey et al., 1993) and sulphides (Morse and Luther, 1999) at the solidwater interface. Casey et al. (1993) reported that the water exchange rate of the hydrated ion is particularly low for $\mathrm{Ni}^{2+}$ $\left(10^{4.4} \mathrm{~s}^{-1}\right)$ compared to that for $\mathrm{Fe}^{2+}\left(10^{6.5} \mathrm{~s}^{-1}\right)$ and that this difference may explain the lower dissolution rate of $\mathrm{Ni}$-oxides and orthosilicates compared to their Fe analogues. In addition, Morse and Luther (1999) proposed that, since $\mathrm{Ni}^{2+}$ has lower kinetics of water exchange than $\mathrm{Fe}^{2+}$, incorporation of $\mathrm{Ni}^{2+}$ into $\mathrm{FeS}_{2}$ should be kinetically favoured over precipitation of pure $\mathrm{NiS}_{2}$, as we demonstrate here.
Our results dispute the common assumption that supersaturation and interfacial energy exert a major control on the kinetics of pyrite nucleation when nickel is present as impurity. They rather suggest that the reactivity of nickel impurities, possibly in the form of $\mathrm{Ni}^{2+}{ }_{\text {aq }}, \mathrm{Fe}_{1-x} \mathrm{Ni}_{x} \mathrm{~S}$ or NiS, could accelerate pyrite nucleation. Further studies of the $\mathrm{S}$ and $\mathrm{O}$ ligand exchange reactions in $\mathrm{Fe}-\mathrm{Ni}-\mathrm{S}-\mathrm{H}_{2} \mathrm{O}$ system are thus required to elucidate the actual mechanism of this kinetic effect.

Implications for present and ancient marine biogeochemistry. Acceleration of pyrite nucleation in the presence of nickel impurity (Figs. 1 and 2) could help explain the particular catalytic role of $\mathrm{Ni}$ in model reaction of the prebiotic chemistry. Indeed, when added to a $\mathrm{FeS}_{(\mathrm{m})}$ precursor, $\mathrm{Ni}$ has been found to facilitate the conversion of $\mathrm{CO}$ and $\mathrm{CH}_{3} \mathrm{SH}$ into the activated thioester $\mathrm{CH}_{3}-\mathrm{CO}-\mathrm{SCH}_{3}$ (Huber and Wächtershäuser, 1997), as well as the polymerisation of peptides from amino-acids (Huber and Wächtershäuser, 1998).

In addition, we show that the accelerated nucleation of pyrite in the presence of $\mathrm{Ni}$ leads to a compositional zoning of the pyrite nanocrystals, with a Ni-rich core and a Ni-depleted outer shell almost devoid of Ni compared to the average crystal (Fig. 3). Consequently, the Ni/Fe molar ratio in the aqueous solution after the precipitation of such inhomogeneous pyrite is 2000 times lower than the starting ratio of 0.01 in our synthesis (Fig. 4b). This effect is expected to dramatically decrease $\mathrm{Ni}$ concentration in the aqueous phase during early diagenesis of euxinic sediments, which may have important implications for the preservation of marine water quality. For instance, fast incorporation of $\mathrm{Ni}$ in pyrite could explain the efficiency of this trapping process in mangrove sediments (Noël et al., 2014, 2015), especially in downstream lateritic Ni-ores, where sedimentary pyrite exhibits $\mathrm{Ni}$ contents as high as in the present study (1-5 mol. \%; Noël et al., 2015).

Finally, an enhanced sequestration of $\mathrm{Ni}$ in pyrite during early diagenesis of sediments at low temperature could also have influenced the distribution of pyrite and nickel in the ancient sedimentary record. For instance, it may help explain both the exceptionally high $\mathrm{Ni}$ contents (up to 1-3 mol. \%) found in marine pyrite from the late Archean ocean and the apparent $\mathrm{Ni}$ enrichment observed in the core of some of these 
pyrite grains (Large et al., 2017). Furthermore, it could be inferred that rapid precipitation of $\mathrm{Ni}$-rich pyrite in euxinic basins of the late Archean ocean (Reinhard et al., 2009; Large et al., 2017) would be expected to have drastically lowered the $\mathrm{Ni} / \mathrm{Fe}$ ratio of the ocean, as observed by Konhauser et al. (2009) in BIFs, which could have contributed to trigger the GOE, as proposed by the latter authors.

\section{Acknowledgements}

This study was funded by an ANRT-UPMC/CNRS/IRD/ IPGP-KNS collaborative research programme. We are greatly indebted to S. Capo (KNS), G. Marakovic (KNS), and C. Marchand (IRD) for the field part of the programme published elsewhere. We acknowledge the help of I. Esteve (CNRS) for SEM, L. Delbes (UPMC) and F. Gélébart (CNRS) for anoxic XRD, L. Cordier (Univ. Paris 7) for ICP-AES, A-L. Auzende (Univ. Genoble-Alpes) for TEM analyses. E. Fonda, V. Briois at SOLEIL, Olivier Mathon at ESRF and M. Munoz (CNRS), are greatly acknowledged for their technical support during EXAFS measurement.

\section{Editor: Simon Redfern}

\section{Additional Information}

Supplementary Information accompanies this letter at www. geochemicalperspectivesletters.org/article1738

Reprints and permission information are available online at http://www.geochemicalperspectivesletters.org/ copyright-and-permissions

Cite this letter as: Morin, G., Noël, V., Menguy, N., Brest, J., Baptiste, B., Tharaud, M., Ona-Nguema, G., Ikogou, M., Viollier, E., Juillot, F. (2017) Nickel accelerates pyrite nucleation at ambient temperature. Geochem. Persp. Let. 5, 6-11.

\section{References}

BERNER, R.A. (1970) Sedimentary pyrite formation. American Journal of Science 268, 1-23.

Bruno, J., Bosbach, D., Kulik, D., Navrotsky, A. (2007) Chemical thermodynamics of solid solutions of interest in radioactive waste management. A state-of-the-art report. In: Mompean, F.J., Illemassène, M. (Eds.) Chemical Thermodynamics Vol. 10. NEA TDB project, OECD Nuclear Energy Agency, Data Bank, Issy-les-Moulineaux, France.

Casey, W.H., Banfield, J.F., Westrich, H.R., MCLaughlin, L. (1993) What do dissolution experiments tell us about natural weathering? Chemical Geology 105, 1-15.

Catling, D.C. AND Claire, M.W. (2005) How Earth's atmosphere evolved to an oxic state: A status report. Earth and Planetary Science Letters 237, $1-20$

Darnaud, C., Volbeda, A., Kim, E.J., Legrand, P.,Vernède, $X$. LiNDAHL, P.A., FONTECILlA-CAMPS, J.C. (2003) Ni-Zn-[Fe4-S4] and $\mathrm{Ni}-\mathrm{Ni}$-[Fe4-S4] clusters in closed and open $\alpha$ subunits of acetyl-CoA synthase/carbon monoxide dehydrogenase. Nature Structural Biology 10, 271-279

Gamsjäger, H., Bugajski, J., Gajda, T., Lemire, R.J., Preis, W. (2005) Chemical thermodynamics of Nickel. In: Mompean, F.J., Illemassène, M. (Eds.) Chemical Thermodynamics Vol. 6. Nuclear Energy Agency Data Bank, Organisation for Economic Co-operation and Development, North Holland Elsevier Science Publishers B.V., Amsterdam, The Netherlands.

Harmandas, N.G., Navarro Fernandez, E., Koutsoukos, P.G. (1998) Crystal Growth of Pyrite in Aqueous Solutions. Inhibition by Organophosphorus Compounds. Langmuir 14, 1250.

Huber, C., WÄchtershäuser, G. (1997) Acetic Acid by Carbon Fixation on (Fe,Ni)S Under Primordial Conditions. Science 276, 245-247.
Huber, C., WÄChtershäUSER, G. (1998) Peptides by Activation of Amino Acids with $\mathrm{CO}$ on $(\mathrm{Ni}, \mathrm{Fe}) \mathrm{S}$ Surfaces: Implications for the Origin of Life. Science 281, 670-672.

Huerta-DiaZ, M.A., Morse, J.W. (1992) Pyritization of trace metals in anoxic marine sediments. Geochimica et Cosmochimica Acta 56, 2681-2702.

Johnson, C.M., BeARD, B.L., Roden, E.E. (2008) The Iron Isotope Fingerprints of Redox and Biogeochemical Cycling in Modern and Ancient Earth. Annual Review of Earth and Planetary Science 36, 457-493.

Kitchaev, D.A., Ceder, G. (2016) Evaluating structure selection in the hydrothermal growth of $\mathrm{FeS}_{2}$ pyrite and marcasite. Nature Commmunications 7, 13799 .

Konhauser, K.O., Pecoits, E., Lalonde, S.V., Papineau, D., Nisbet, E.G., Barley, M.E., Arndt, N.T., Zahnle, K., Kamber, B.S. (2009) Oceanic nickel depletion and a methanogen famine before the Great Oxidation Event. Nature 458, 750-754.

Large, R.R., Mukherjee, I., Gregory, D.D., Steadman, J.A., MaslenNIKOV, V.V., MefFre, S. (2017) Ocean and Atmosphere Geochemical Proxies Derived from Trace Elements in Marine Pyrite: Implications for Ore Genesis in Sedimentary Basins. Economic Geology, 112, 423-450.

Lennie, A.R., Redfern, S.A.T., Schofield, P.F., VAughan, D.J. (1995) Synthesis and Rietveld crystal structure refinement of mackinawite. Mineralogical Magazine 59, 677-683.

LUtHer, G.W. (1991) Pyrite synthesis via polysulfide compounds. Geochimica et Cosmochimica Acta, 55, 2839-2849.

Marin-Carbonne, J., Rollion-Bard, C., Bekker, A., Rouxel, O., Agangi, A., Cavalazzi, B., Wohlgemuth-Ueberwasser, C.C., Hofmann, A., McKeEgan, K.D. (2014) Coupled Fe and S isotope variations in pyrite nodules from Archean shale. Earth and Planetary Science Letters 392, 67-79.

Morse, J.W., Luther III, G.W. (1999) Chemical influences on trace metal-sulfide interactions in anoxic sediments. Geochimica et Cosmochimica Acta 63, 3373-3378.

Noël, V., Marchand, C., Juillot, F., Ona-Nguema, G., Viollier, E., Marakovic, G., Olivi, L., Delbes, L., Gelebart, F., Morin, G. (2014) EXAFS analysis of iron cycling in mangrove sediments downstream of a lateritized ultramafic watershed (Vavouto Bay, New Caledonia). Geochimica et Cosmochimica Acta 136, 211-228.

NoËL, V., Morin, G., Juillot, F., Marchand, C., Brest, J., BARGar, J.R., Muñoz, M., Marakovic, G., Ardo, S., Brown Jr., G.E. (2015) $\mathrm{Ni}$ cycling in mangrove sediments from New Caledonia. Geochimica et Cosmochimica Acta 169, 82-98.

Ohmoto, H., Watanabe, Y., Ikemi, H., Poulson, S.R., Taylor B.E. (2006) Sulphur isotope evidence for an oxic Archaean atmosphere. Nature Letter 442, 908-911.

Reinhard, C.T., Raiswell, R., Scott, C., Anbar, A.D., Lyons, T.W. (2009) A late Archean sulfidic sea stimulated by early oxidative weathering of the continents. Science 326, 713-716.

RICKARD, D.T. (1975) Kinetics and mechanism of pyrite formation at low-temperature. American Journal of Science 275, 636-652.

RickARD, D.T., MORSE J. (2005) Acid volatile sulfide (AVS) Marine Chemistry 97, 141.

Rickard, D.T., Luther, G.W. (2007) Chemistry of Iron Sulfides. Chemical Reviews 107, 514-562.

Rouxel, O.J., BeKKer, A., EdwARds, J. (2005) Iron Isotope Constraints on the Archean and Paleoproterozoic Ocean Redox State. Science 307, 1088-1091.

SchoOnen, M.A.A., BARnes, H.L. (1991) Reactions forming pyrite and marcasite fom solution 2. Via FeS precursors below $100^{\circ} \mathrm{C}$. Geochimica et Cosmochimica Acta 55, 1505-1514.

STUMM, W. (1992) Chemistry of the solid-water interface. John Wiley \& Sons, Inc., New York.

THEBerge, S., LutHeR, G.W. (1997) Determination of the electrochemical properties of a soluble aqueous FeS species present in sulfide solutions. Aquatic Geochemistry 3, 191-211.

VAN DER LEE, J., DE WINDT, L. (2002) CHESS Tutorial and Cookbook. Updated for version 3.0. Users Manual Nr. LHM/RD/02/13. Ecole des Mines de Paris, Fontainebleau, France.

Wyckoff, R.W.G. (1963) Crystal Structures. Second Edition, Volumes 1-6. Interscience, New York.

ZHenG, J., ZHOU, W., MA, Y., CAO, W., WANG, C., GUO, L. (2015) Facet-dependent $\mathrm{NiS}_{2}$ polyhedrons on counter electrodes for dye-sensitized solar cells. Chemical Communications 51, 12863. 